\title{
rDNA mapping, heterochromatin characterization and AT/GC content of Agapanthus africanus (L.) Hoffmanns (Agapanthaceae)
}

\author{
ARYANE C. REIS, ANA LUIZA FRANCO, VICTÓRIA R. CAMPOS, FLÁVIA R. SOUZA, \\ CRISTIANE ZORZATTO, LYDERSON F. VICCINI and SAULO M. SOUSA \\ Departamento de Biologia, Laboratório de Genética e Biotecnologia, Universidade Federal de \\ Juiz de Fora, Rua José Lourenço Kelmer, s/n, 36036-900 Juiz de Fora, MG, Brasil
}

Manuscript received on August 3, 2015; accepted for publication on November 27, 2015

\begin{abstract}
Agapanthus (Agapanthaceae) has 10 species described. However, most taxonomists differ respect to this number because the great phenotypic plasticity of the species. The cytogenetic has been an important tool to aid the plant taxon identification, and to date, all taxa of Agapanthus L'Héritier studied cytologically, presented $2 \mathrm{n}=30$. Although the species possess large chromosomes, the group is karyologically little explored. This work aimed to increase the cytogenetic knowledge of Agapanthus africanus (L.) Hoffmanns by utilization of chromosome banding techniques with DAPI / $\mathrm{CMA}_{3}$ and Fluorescent in situ Hybridization (FISH). In addition, flow cytometry was used for determination of DNA content and the percentage of AT / GC nitrogenous bases. Plants studied showed $2 \mathrm{n}=30$ chromosomes, ranging from $4.34-8.55 \mu \mathrm{m}$, with the karyotype formulae $(\mathrm{KF})=10 \mathrm{~m}+5 \mathrm{sm}$. Through FISH, one $45 \mathrm{~S}$ rDNA signal was observed proximally to centromere of the chromosome 7 , while for $5 \mathrm{~S}$ rDNA sites we observed one signal proximally to centromere of chromosome 9. The $2 \mathrm{C}$ DNA content estimated for the species was $2 \mathrm{C}=24.4$ with $59 \%$ of AT and $41 \%$ of GC. Our data allowed important upgrade for biology and cytotaxonomy of Agapanthus africanus (L.) Hoffmanns.
\end{abstract}

Key words: African lily, chromosome banding, cytotaxonomy, flow cytometry, genome size, molecular cytogenetics.

\section{INTRODUCTION}

The genus Agapanthus L'Héritier (Agapantahceae) is a monocotyledonous, herbaceus and perennial plant group endemic to southern Africa, with ten species in which three are considered evergreen and seven deciduous plants (Leighton 1965). Nevertheless, Agapanthus L'Héritier taxonomy

Correspondence to: Saulo Marçal de Sousa

E-mail: saulo.marcal@ufjf.edu.br /

saulo_marcal@yahoo.com.br is considered very difficult once there are few unique characters and a high plasticity depending on circumstances of growing. This feature takes some authors to believe in the existence of only one species with innumerous varieties (McNeil 1972). So, the obtaining and exploring of new characters, less plastic to identification of these species are of great importance for Agapanthus L'Héritier taxonomy. 
The use of karyological data in taxonomy, contribute widely to evaluate the genetic relationship among species or populations and to a better understanding of the way they diverged from each other (Guerra 2008, Sousa et al. 2013, Reis et al. 2014). In Agapanthus L'Héritier, all plants measured until the moment have the same chromosome number, $2 \mathrm{n}=30$ (Riley and Mukerjee 1960, Sharma and Mukhopadhyay 1963), with little differences only in chromosome length. Since chromosome length can vary with condensation, this parameter in plastic plants, studied without another chromosome marker is not a good tract for detection of speciation. For this, more detailed karyological studies are very important to increment the utilization of chromosome length like a parameter of species identification in Agapanthus L'Héritier.

Agapanthus africanus (L.) Hoffmanns, an endemic South African species, highly desired as ornamental, has been grown around the world, being adapted to conditions in Europe, Australia, New Zealand and North as well as South America, since the late seventeenth century (Win Snoeijer 2004). Besides its ornamental attributes the species are traditionally used by local communities in South Africa as medicinal for various disorders: during pregnancy to induce labour (Kaido et al. 1997); to treat constipation in pregnancy (Van Wyk et al. 1997); as antenatal or post-natal treatment of the mother and for high blood pressure (Duncan et al. 1999). Additionally some studies have shown that Agapanthus africanus (L.) Hoffmanns has an important antifungal potential against plant pathogens (Singh et al. 2008, Tagegne et al. 2008).

Due its varied application and importance around the world, the aim of the present work was to obtain new chromosomal markers for Agapanthus africanus (L.) Hoffmanns (an important informations for taxonomy and breeding of the species) utilizing molecular cytogenetics, chromosomes banding and flow cytometry which are scarce approaches for the genus.

\section{MATERIALS AND METHODS}

\section{PLANT MATERIAL AND PREPARATION OF MITOTIC SPREADS}

Seeds of Agapanthus africanus (L.) Hoffmanns were collected at three different sites: Bom Pastor

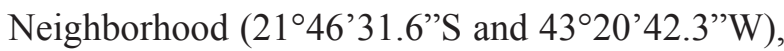
São Pedro Neighborhood $\left(21^{\circ} 46>19.9 » S\right.$ and $\left.43^{\circ} 22>39.1 » \mathrm{~W}\right)$, and in the Cam pus of the Federal University of Juiz de Fora (21 46'23.3"S and $43^{\circ} 22^{\prime} 09.3^{\prime \prime W}$ ), in Juiz de Fora Minas Gerais, Brazil. For each locality around 50 seeds were collected and herbarium voucher specimens were deposited at the CESJ Herbarium of the Federal University of Juiz de Fora (available at http://www. splink.org.br).

After that, seeds were germinated and roots tips were pre-treated with 8-hydroxyquinoline solution $(0.003 \mathrm{M})$ at room temperature for $9 \mathrm{~h}$ and then fixed in ethanol and acetic acid $(3: 1 \mathrm{v} / \mathrm{v})$ for $24 \mathrm{~h}$ at $-20^{\circ} \mathrm{C}$. Root meristems were submitted to enzymatic maceration (2\% Celullase: $20 \%$ Pectinase) for $5 \mathrm{~h}$ at $37^{\circ} \mathrm{C}$. The slides were prepared according to Carvalho and Saraiva (1993, 1997).

CHROMOSOME MORPHOMETRY

Chromosome length, short and long arms length and ratio between chromosome arms were measured and chromosome classification was done according to Levan et al. (1964). The ideogram was mounted according to decreasing size order of chromosomes short arms.

\section{CHROMOSOME BANDING}

Chromosome banding was performed according Schweizer (1976). Five aged slides from each localities were stained with chromomycin $\mathrm{A}_{3}(0.5$ $\mathrm{mg} / \mathrm{mL})$ for $1 \mathrm{~h}$, dystamicyn $(0.1 \mathrm{mg} / \mathrm{mL})$ for 30 min and 2-4 diamidino-2-phenylindole $(2 \mu \mathrm{g} / \mathrm{mL})$ for $30 \mathrm{~min}$. The slides were mounted in Mcllvaine's 
pH 7.0 buffer-glycerol $(1: 1 \mathrm{v} / \mathrm{v})$. For this analysis ten metaphases from plants of each locality were observed and captured in an Olympus DP72 digital camera. The chromosomes were observed using an epifluorescence microscope (Olympus BX 51) with appropriate filter set.

After images documentation the slides were discolored in $100 \%$ ethanol for $24 \mathrm{~h}$ at room temperature and used for molecular cytogenetic processes.

\section{Molecular Cytogenetic}

Fluorescence in situ hybridization (FISH) was performed using 45S rDNA probes from Triticum aestivum L. (Gerlach and Bedbrook 1979) and $5 \mathrm{~S}$ probes from Zea mays L. (courtesy Koo and J. Jiang). Each probe was labeled with digoxigenin by nick translation and then hybridized according to Jiang et al. (1995) with minor modifications. The hybridization mixture was denatured at $85^{\circ} \mathrm{C}$ for $10 \mathrm{~min}$ and immediately transferred to an icebox. The slides were denatured at $85^{\circ} \mathrm{C}$ for $1 \mathrm{~min}$ and treated with a series of ethanol washes $(70 \%$, $90 \%$, and $100 \%$ for $5 \mathrm{~min}$ each). The hybridization mixture was then added to the slides and the chromosomes allowed to hybridize at $37^{\circ} \mathrm{C}$ for $48 \mathrm{~h}$. Posthybridization washes were carried out using 2 $\times$ SSC buffer for $15 \mathrm{~min}$ and $1 \times$ PBS buffer for 5 min. Probes were detected with anti-DIG conjugate with rhodamine and postdetection washes were performed using $1 \times$ TNT buffer and for $15 \mathrm{~min}$ and $1 \times$ PBS buffer for $5 \mathrm{~min}$ at room temperature. Chromosomes were counter-stained with $2 \mu \mathrm{g} / \mathrm{mL}$ of DAPI. The slides were mounted in Vectashield (Vector) and samples were rehybridized after slides discoloration in $100 \%$ ethanol for $24 \mathrm{~h}$. Images with $45 \mathrm{~S}$ and $5 \mathrm{~S}$ signals were merged using CellSens software (Olympus). Chromosomes were observed using an epifluorescence microscope (Olympus BX 51) with appropriate filter set.
FLOW CYTOMETRY (FCM)

Nuclear DNA content was determined according to the method of Galbraith et al. (1983). Approximately 20-30 mg of young and fresh leaves of 3 plants of Agapanthus africanus (L.) Hoffmanns from each locality and the same amount of young foliar tissue of standard references (Pisum sativum L.) were chopped on ice with $1 \mathrm{~mL}$ ofOTTO I lysis buffer solution (0.1 M $\mathrm{C}_{6} \mathrm{H}_{8} \mathrm{O}_{7} ; 0.5 \%$ Tween 20) (Otto 1990) supplemented with $50 \mu \mathrm{g} / \mathrm{mL}^{-1}$ RNAse. The suspension was filtered through 40nm mesh into $2 \mathrm{~mL}$ microcentrifuge tube and centrifuged at 1,100 rpm for 5 minutes. The pellet was incubated in $100 \mu \mathrm{L}$ OTTO I lysis buffer for 10 minutes and then was added $300 \mu \mathrm{L}$ of OTTO I: OTTO II $\left(0.4 \mathrm{M} \mathrm{Na}_{2} \mathrm{HPO}_{4} .12 \mathrm{H}_{2} \mathrm{O}\right)(1: 2, \mathrm{v} / \mathrm{v})$ buffers. The sample were homogenized and stained with 50 $\mu \mathrm{g} / \mathrm{mL}^{-1}$ of propidium iodide (PI) to determine the total DNA content.

AT/GC composition was determined by adding DAPI (4,6-diamidino-2-phenylindole) $4 \mu \mathrm{g} / \mathrm{mL}^{-1}$ to the samples. At least 10,000 nuclei were analyzed per sample in a FACSCantoII (BectonDickinson) flow cytometer. The histograms were analyzed using Flowing 2.5.1 software (www.flowingsoftware.com).

DNA nuclear content (pg) of each sample was estimated by the relative fluorescence intensity of the sample and the internal reference standard (Pisum sativum L. 9.09 pg). Three samples, of each accession, were measured according to the following equation (Dolezel 2003):

DNA content of sample $=\frac{\text { PIFI of sample X DNA content of standard }}{\text { PIFI of standard }}$

(PIFI is the fluorescence intensity of propidium iodide in $\mathrm{G}_{1}$ cells).

The AT percentage of Agapanthus africanus (L.) Hoffmanns was measured in relation to $P$. sativum L. reference standard, following the formula described by Godelle et al. (1993):

$$
A T \text { sample }=A T \text { standard }(R D A P I / R I P)^{1 / r}
$$


TABLE I

Karyology of $A$. africanus and estimative of DNA content for each chromosome.

\begin{tabular}{|c|c|c|c|c|c|c|c|c|}
\hline Chromosome & $\begin{array}{c}\text { Relative } \\
\text { lenght } \\
(\%)\end{array}$ & $\begin{array}{c}\text { Absolute } \\
\text { lenght }(\mu \mathrm{m})\end{array}$ & $\begin{array}{c}\text { Short arm } \\
\text { length } \\
(\mu \mathrm{m})\end{array}$ & $\begin{array}{c}\text { Long arm } \\
\text { Length } \\
(\mu \mathrm{m})\end{array}$ & Arm ratio & Classification & $\begin{array}{c}\text { DNA pg/ } \\
\text { chromosome }\end{array}$ & $\begin{array}{c}\text { Mpb/ } \\
\text { chromosome }\end{array}$ \\
\hline 1 & 9.46 & 8.55 & 3.93 & 4.62 & 1.17 & $\mathrm{~m}$ & 1.15 & 1128.72 \\
\hline 2 & 8.91 & 8.05 & 3.65 & 4.39 & 1.20 & $\mathrm{~m}$ & 1.08 & 1063.10 \\
\hline 3 & 8.91 & 8.05 & 3.42 & 4.63 & 1.35 & $\mathrm{~m}$ & 1.08 & 1063.10 \\
\hline 4 & 6.71 & 6.07 & 2.93 & 3.14 & 1.07 & $\mathrm{~m}$ & 0.81 & 800.61 \\
\hline 5 & 7.17 & 6.48 & 2.71 & 3.77 & 1.38 & $\mathrm{~m}$ & 0.87 & 855.49 \\
\hline 6 & 7.42 & 6.70 & 2.64 & 4.06 & 1.53 & $\mathrm{~m}$ & 0.90 & 885.32 \\
\hline 7 & 7.55 & 6.82 & 2.40 & 4.42 & 1.84 & $\mathrm{sm}$ & 0.92 & 900.83 \\
\hline 8 & 5.81 & 5.25 & 2.21 & 3.04 & 1.37 & $\mathrm{~m}$ & 0.70 & 693.22 \\
\hline 9 & 6.44 & 5.82 & 2.14 & 3.68 & 1.71 & $\mathrm{sm}$ & 0.78 & 768.39 \\
\hline 10 & 5.49 & 4.96 & 2.07 & 2.79 & 1.34 & $\mathrm{~m}$ & 0.66 & 655.04 \\
\hline 11 & 5.37 & 4.86 & 2.05 & 2.90 & 1.41 & $\mathrm{~m}$ & 0.65 & 640.72 \\
\hline 12 & 4.92 & 4.44 & 1.86 & 2.58 & 1.38 & $\mathrm{~m}$ & 0.60 & 587.03 \\
\hline 13 & 5.40 & 4.88 & 1.66 & 3.22 & 1.93 & $\mathrm{sm}$ & 0.66 & 644.30 \\
\hline 14 & 5.57 & 5.03 & 1.56 & 3.47 & 2.22 & $\mathrm{sm}$ & 0.67 & 664.59 \\
\hline 15 & 4.80 & 4.34 & 1.46 & 2.88 & 1.97 & $\mathrm{sm}$ & 0.58 & 572.71 \\
\hline
\end{tabular}

$\mathbf{p g}=$ picograms $; \mathbf{M p b}=$ Megabase pairs $; \boldsymbol{\mu m}=$ micrometer $; \mathbf{m}=$ median; $\mathbf{s m}=$ submedian.

( $R$ is the ratio of fluorescence intensity between the peak of Agapanthus africanus (L.) Hoffmanns and Pisum sativum L., and $\mathrm{r}$ (binding length) $=3$ for DAPI dye).

The percentage of the complementary bases was calculated as $\mathrm{GC} \%=100-\mathrm{AT} \%$.

Taking into account that $1 \mathrm{pg}=978 \mathrm{Mpb}$ (Dolezel et al. 2003), the combination of cytometric and cytogenetic data were provided.

\section{RESULTS AND DISCUSSION}

Samples of Agapanthus africanus (L.) Hoffmanns from the three different localities studied here showed symmetrical karyotype with $2 \mathrm{n}=30$, of which ten chromosomes with centromeres at the median region $(\mathrm{m}$, Arm Ratio $=1-1.7)$, and five of them at submedian (sm, Arm Ratio $=$ 1.71 - 3.0) (Table I). No secondary constrictions were observed and absolute chromosome length ranged from $4.34-8.55 \mu \mathrm{m}$ (Table I) while the relative chromosome length revealed that the largest chromosome represented around 9.46\% of the genome size and the shortest one $4.80 \%$ (Table I). Our results are in conformity with the cytogenetics morphometric data in the literature for Agapanthus L'Héritier (Riley and Mukerjee 1962, Sharma and Mukhopadhyay 1963, Yaacob and Taha 2014), however, no cytogenetics data for the taxa Agapanthus africanus (L.) Hoffmanns has been described. In the most recent revision of the genus (Win Snoeijer 2004) Agapanthus africanus (L.) Hoffmanns is considered like synonymy of Agapanthus minor Lodd., Agapanthus umbellatus L'Héritier, Agapanthus umbelliferus Poir., Agapanthus tuberosus L. ex DC. and Agapanthus variegatus Steud. Sharma and Mukhopadhyay (1963) studing the cytogenetics of varieties of Agapanthus umbellatus L'Hér. observed a very similar chromosomal morphology with the data observed for us, principally when we compare it with 

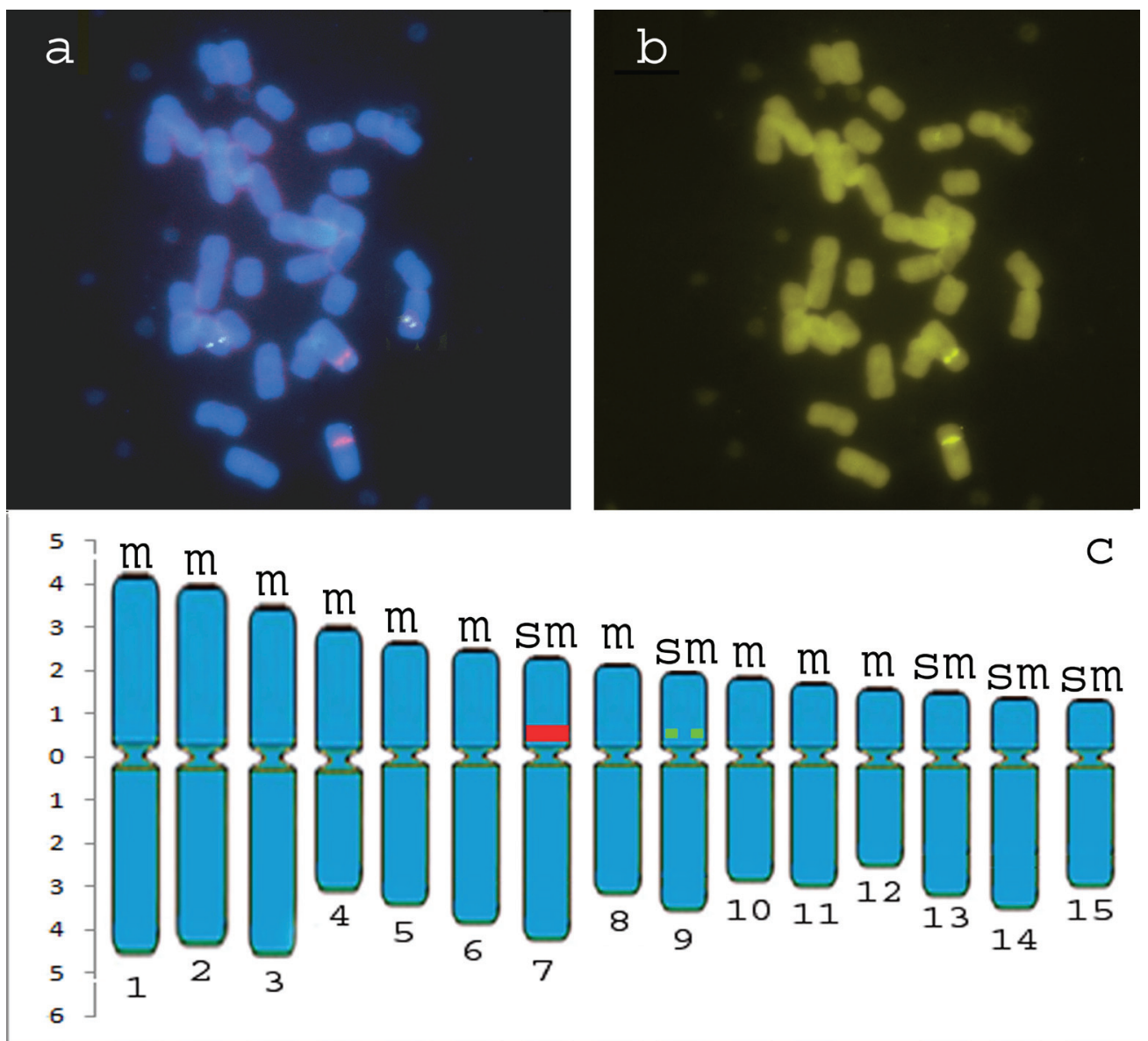

Figure 1 - Representative metaphases with 5S rDNA and 45S rDNA mapping (a); CMA banding pattern (b) and Ideogram of Agapanthus africanus (L.) Hoffmanns (c) (green squares= 5S rDNA, red rectangle $=45 \mathrm{~S}$ rDNA), $\mathrm{m}=$ metacentric and $\mathrm{sm}=$ submetacentric.

the taxa Agapanthus umbellatus var. intermedius Tubergen where the size of chromosomes varied from 4.1-8.9 $\mu \mathrm{m}$, with all chromosomes with centromeres at median and sub-median regions. Nevertheless, theses authors observed one pair of chromosomes with secondary constrictions, no observed in our work with DAPI coloration.

Although chromosomes in Agapanthus L'Héritier are very large and of easy obtainment, the cytogenetics of the group is very little explored. Our observations are the first data related to molecular cytogenetics and with the mapping of heterochromatin for the genus. The $45 \mathrm{~S}$ rDNA signal was observed in one chromosome pair on the interstitial portion, proximally to the centromere (in the short arm of chromosome 7) (Fig. 1a, c), while 5S rDNA signals was observed in interstitial portion, proximally to the centromere, in the short arm of chromosome 9 (Fig. 1a, c). The 45S rDNA sites showed greater bands when compared with those ones observed for 5S rDNA sites, which showed pairs of little dots (Fig. 1a, c). This experiment was very important to determine the number of rDNA sites in this species once no secondary constrictions were observed in the slides prepared here. Once again our data are in conformity with observations of Sharma and Mukhopadhyay (1963) for the Agapanthus umbellatus var. intermedius Tubergen since these authors observed one pair of secondary constrictions (these data indicate that at 

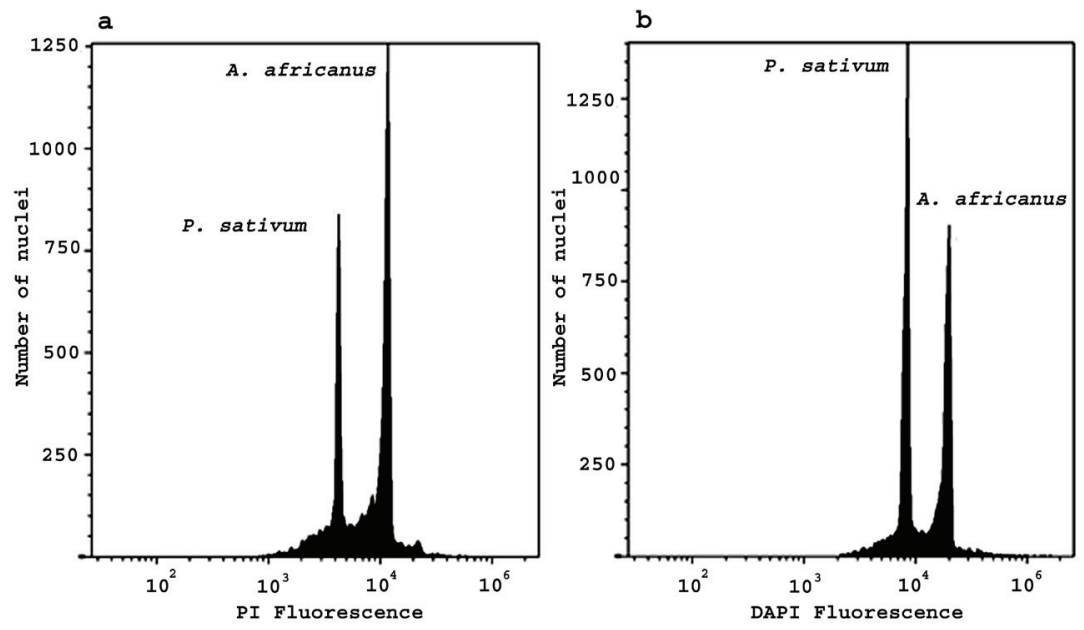

Figure 2 - Flow cytometry histograms representing Agapanthus africanus (L.) Hoffmanns using Pisum sativum L. (9.09 pg) as internal standard. (a) The fluorochrome propidium iodide (PI) was used to measurement of DNA amount (24.4 pg; CV=2.47) (2C values). (b) The fluorochrome 4',6-diamidino-2-phenylindole (DAPI) was used to determine the AT base percentual $(59 \% ; \mathrm{CV}=1.64)$.

least one pair of $45 \mathrm{~S}$ rDNA is present in this species once that in major plants this sites are coincident). Nevertheless, like us, Panzera et al. (1996) also observed in Allium cepa L. sites of active 45S rDNA no coincident with secondary constrictions, confirming that these sites can or can't form secondary constrictions.

For the chromosome banding, no centromeric, interstitial or terminal DAPI bands were observed. However, fluorochrome staining with $\mathrm{CMA}_{3}$ revealed bands on chromosome pair 7, which were also DAPI negative (Fig. 1b). The observed bands in homologues chromosomes showed similar size and bright being coincident with 45S rDNA (Fig. $1 \mathrm{a}, \mathrm{b})$, a common feature in a wide variety of plants (Sumner 1990, Guerra and Felix 2000, Sousa et al. 2013). No additional CMA bands were observed in any of the chromosome pairs (Fig. 1b).

Regardingtothenucleargenomesize estimation, the FCM provided high quality histograms with $\mathrm{G}_{0} /$ $\mathrm{G}_{1}$ peaks showing $\mathrm{CV}=2.47$. The $2 \mathrm{C}$ DNA content estimated for the species was $2 \mathrm{C}=24.4 \mathrm{pg}$. Taking into account that $1 \mathrm{pg}=978 \mathrm{Mpb}$ (Dolezel et al. 2003), and combining cytometric and cytogenetic data, the largest chromosome (chromosome 1) corresponds to $1128.72 \mathrm{Mpb}(\sim 9.5 \%$ of the genome), while the smallest one (chromosome 15) corresponds to $572.71 \mathrm{Mpb}(\sim 4.8 \%$ of the genome) (Table I). Genome size, obtained by flow cytometry has been successfully used to investigate Agapanthus L'Héritier (Zonneveld 2004). When all species in a genus have the same chromosome number, as in Agapanthus L'Héritier, differences in nuclear DNA content have proven to be very effective in delimiting of infrageneric divisions in a number of taxa (Ohri 1998, Zonneveld 2004). With this approaches, Zonneveld and Duncan (2003) suggest that there are six species in Agapanthus L'Héritier and not ten as described by Leigthon (1965). The species in this context would be: Agapanthus campanulatus F. M. Leight. $(2 \mathrm{C}=$ $22.3 \mathrm{pg})$, Agapanthus caulescens Spreng. (2C = $23.2 \mathrm{pg})$, Agapanthus coddii F.M.Leight. (2C = $24.0 \mathrm{pg})$, Agapanthus praecox Willd. $(2 \mathrm{C}=25.5$ pg), Agapanthus inapertus Beauverd (2C $=25.1$ pg), and Agapanthus africanus (L.) Hoffmanns $(2 \mathrm{C}=31.6 \mathrm{pg})$, while the other four, according to the new proposal, would receive a status below 
species rank. When compared with the value observed for Zonneveld and Duncan (2003), the DNA content obtained by us $(2 \mathrm{C}=24.4 \mathrm{pg})$ is very next of Agapanthus coddii F. M. Leight. $(2 \mathrm{C}=24.0$ pg) while the content obtained for Agapanthus africanus (L.) Hoffmanns for these authors was different of our $(2 \mathrm{C}=31.6 \mathrm{pg})$. Once more, this observation shows the great intraspecific variation observed in the genus.

In addition to the DNA content, PI and DAPI fluorochromes index allowed, for the first time, the estimation of base composition of the genome of Agapanthus africanus (L.) Hoffmanns. The percentage of base was $59 \%$ for AT and $41 \%$ for GC. The representative histograms of DNA content and base composition can be seen in figure 2 .

Finally, our data constitute an important upgrade in the biology of the Agapanthus africanus (L.) Hoffmanns, and can be used to future taxonomic, phylogenetic studies and for the chromosome evolution of the genus.

\section{ACKNOWLEDGMENTS}

The authors wish to thank Fundação de Amparo à Pesquisa do Estado de Minas Gerais (FAPEMIG), Coordenação de Aperfeiçoamento de Pessoal de Nível Superior (CAPES), and Conselho Nacional de Desenvolvimento Científico e Tecnológico (CNPq) for financial support.

\section{RESUMO}

Agapanthus (Agapanthaceae) possui 10 espécies descritas. No entanto a maioria dos taxonomistas difere relativamente a este número, devido à grande plasticidade fenotípica das espécies. A citogenética tem sido uma ferramenta importante para auxiliar a identificação de taxa de plantas, e até o momento, todas as espécies de Agapanthus L'Héritier estudadas citologicamente, apresentaram $2 \mathrm{n}=30$. Embora as espécies possuam grandes cromossomos, o grupo é cariologicamente pouco explorado. Este trabalho teve como objetivo aumentar o conhecimento citogenético de Agapanthus africanus (L.) Hoffmanns pela utilização de técnicas de bandeamento cromossômico com DAPI / $\mathrm{CMA}_{3} \mathrm{e}$ Hibridização in situ Fluorescente (FISH). Além disso, a citometria de fluxo foi utilizada para a determinação do conteúdo de DNA e do percentual de bases nitrogenadas AT e GC. As plantas estudadas apresentaram $2 \mathrm{n}=$ 30 cromossomos, variando de 4,34 - 8,55 $\mu \mathrm{m}$, com a fórmula cariotípica $(\mathrm{KF})=10 \mathrm{~m}+5 \mathrm{sm}$. Através da FISH, um sinal para rDNA $45 \mathrm{~S}$ foi observada proximalmente ao centrômero do cromossomo 7, enquanto que para os sítios de rDNA 5S, observamos um sinal proximal ao centrômero do cromossomo 9 . O conteúdo $2 \mathrm{C}$ de DNA estimado para a espécie foi de $2 \mathrm{C}=24,4$ com $59 \%$ de AT e $41 \%$ de GC. Nossos dados possibilitaram uma atualização importante para a biologia e citotaxonomia de Agapanthus africanus (L.) Hoffmanns.

Palavras-chave: lírio Africano, bandeamento cromossômico, citotaxonomia, citometria de fluxo, tamanho do genoma, citogenética molecular.

\section{REFERENCES}

CARVALHO CR AND SARAIVA LS. 1993. A new heterochromatin banding pattern revealed by modified HKG banding technique for maize chromosomes. Heredity 70: 515-519.

CARVALHO CR AND SARAIVA LS. 1997. High-resolution HKG-banding in maize mitotic chromosomes. J Plant Res 110: 417-420.

DOLEZEL J, BARTOS J, VOGLMAYR H AND GREILHUBER J. 2003. Nuclear DNA content and genome size of trout and human. Cytometry 51: 127-128.

DUNCAN A, JAGER AC AND VAN STADEN JK. 1999. Screening of Zulu medicinal plants for angiotensin-converting enzyme (ACE) inhibitors. J Ethnopharmacol 68: 63-70.

GALBRAITH DW, HARKINS KR, MADDOX JM, AYRES NM, SHARMA DP AND FIROOZABADY E. 1983. Rapid flow cytometric analysis of the cell cycle in intact plant tissues. Science 220: 1049-1051.

GERLACH WL AND BEDBROOK JR. 1979. Cloning and characterization of ribosomal RNA genes from wheat and barley. Nucleic Acids Res 7: 1869-1885.

GODELlE B, CARTIER D, MARIE D, BROWN CS AND SILJAKYAKOVLEV S. 1993. Heterochromatin study demonstrating the non-linearity of fluorometry useful for calculatinggenomicbase composition. Cytometry 14: 618-626.

Guerra M. 2008. Chromosome numbers in plant cytotaxonomy: concepts and implications. Cytogenet Genome Res 120: 339-350.

GUERRA M AND FELIX LP. 2000. O cariótipo de Nothoscordum pulchellum (Alliaceae) com ênfase na heterocromatina e sítios de DNAr. Bol Soc Argent Bot 35: 283-289. 
JiANG J, GILL BS, WANG GL, RONALD PC AND WARD DC. 1995. Metaphase and interphase fluorescence in situ hybridization mapping of the rice with bacterial artificial chromosomes. Proc Natl Acad Sci USA 92: 4487- 4491.

KAIDO TL, VEALE DJH, HAVLIK I AND RAMA DBK. 1997. Preliminary screening of plants used in South Africa as traditional herbal remedies during pregnancy and labour. J Ethnopharmacol 55: 185-191.

LEIGHTON FM. 1965. The genus Agapanthus L'Héritier. J South African Bot IV(Suppl.): 1-50.

LEVAN A, Fredga A AND SANDERBER A. 1964. Nomenclature for centromeric position in chromosomes. Hereditas 52: 201-220.

MCNeIL G. 1972. The Katberg Agapanthus. J Roy Hort Soc 97(12): 534-536.

OHRI D. 1998. Genome size variation and plant systematics. Ann Bot 82(Suppl. A): 75-83.

OTTO FJ. 1990. DAPI staining of fixed cells for high-resolution flow cytometry of nuclear DNA. Methods Cell Biol 33: 105-110.

PANZERA F, GIMÉNEZ-ABIÁN MI, LÓPEZ-SÁEZ JF, Giménez-Martin G, CuAdrado A, ShaW PJ, Beven AF, CÁNOVAS JL AND DE LA TORRE C. 1996. Nucleolar organizer expression in Allium cepa L. chromosomes. Chromosoma 105: 12-19.

Reis AC, Sousa SM, VAle AA, PIERre PMO, Franco AL, CAMPOS JMS, VIEIRA RF AND VICCINI LF. 2014. Lippia alba (Verbenaceae): A new tropical autopolyploid complex? Am J Bot 101: 1002-1012.

RILEY HP AND MUKERJEE D. 1960. Chromosomes in Agapanthus. Genetics 45: 1008.

RILEY HP AND MUKERJEE D. 1962. Chromosomes of some species of Agapanthus. Cytologia 27: 325-332.
SCHWEIZER D. 1976. Reverse fluorescent chromosome banding with chromomycin and DAPI. Chromosoma 58: 307324.

SHARMA AK AND MUKHOPADHYAY S. 1963. Chromosome study in Agapanthus and the phylogeny of its species. Caryologia 16: 127-137.

SINGH DN, VERMA N, RAGHUWANShi S, SHUKLA PK AND KULSHRESHTHA DK. 2008. Antifungal activity of Agapanthus africanus extractives. Fitoterapia 79: 298-300.

SOUSA SM, REIS AC AND VICCINI LF. 2013. Polyploidy, B chromosomes and heterochromatin characterization of Mimosa caesalpiniifolia Benth. (Fabaceae-Mimosoideae). Tree Genet Genomes 9: 613-619.

SUMNER AT. 1990. Chromosome banding. Unwin Hyman: Boston, $434 \mathrm{p}$.

TAgegne G, Pretorius JC AND SWArt WJ. 2008. Antifungal properties of Agapanthus africanus L. extracts against plant pathogens. Crop Protection 27: 1052-1060.

VAN WYK BE, VAN OUDTSHOORN B AND GERICKE N. 1997. Medicinal plants of South Africa, Briza Publications, South Africa, p. 32.

WIN SNOEIJER FLS. 2004. Agapanthus: a revision of the genus. Timber Press, 2 Station Road. Swavesey: Cambridge, $320 \mathrm{p}$.

YAACOB JS AND TAHA RM. 2014. Genetic stability of in vitro propagated African blue lily (Agapanthus praecox ssp. minimus). Caryologia 67: 227-233.

ZONNEVELD BJM. 2004. Genome size in species and cultivars of Agapanthus L'Hér. (Agapanthaceae). In: Win Snoeijer FLS (Ed), Agapanthus: a revision of the genus. Timber Press, 2 Station Road. Swavesey: Cambridge, p. 20-36.

ZONNEVELD BJM AND DUNCAN GD. 2003. Taxonomic implications of genome size and pollen colour and vitality for species of Agapanthus L'Héritier (Agapanthaceae). Plant Syst Evol 241: 115-123. 